\title{
Fast Moving Consumer Goods Become a New Retail Trend in India
}

\author{
Rameshbhai G. Pawar ${ }^{1}$, Dr. R. K. Dave ${ }^{2}$ \\ ${ }^{1}$ B. Com., M.Com., Ph.D. Scholar, Saurashtra University, Rajkot, India \\ ${ }^{2}$ Guide of Saurashtra University, Rajkot and Principal, Yogiji Maharaj Mahavidyalay Arts and Commerce College Dhari, Dist. Amreli
}

\begin{abstract}
Price and income elasticity of demand varies across products and consumers. As per ICRA the term FMCG has been defined to include products that are consumed at least once a month, sold under the national brands in consumer packages, sold through a wide spared distribution network and consumed directly by the consumers. FMCG companies sell their products directly to consumers. Major features that distinguish this sector. Typically a consumer buys these goods at regular intervals. These are bought for personal consumption and family care. Consumers keep a little stock of these products and make frequent purchases for these. These individual items are of relatively small value, but all FMCG products put together account for a significant part of the consumers' budget.
\end{abstract}

Keywords: FMCG Concept and characteristics of Different Sector

\section{Introduction}

The term FMCG- Fast moving consumer goods refer to consumer non-durable goods required for daily or frequent use and directly used by the customers. These products cater to necessities, comforts as well as luxuries. They meet the demands of the entire cross sections of population. Price and income elasticity of demand varies across products and consumers. As per ICRA the term FMCG has been defined to include products that are consumed at least once a month, sold under the national brands in consumer packages, sold through a wide spared distribution network and consumed directly by the consumers.

\section{Product Characteristics}

Products belonging to the FMCG segment generally have the following characteristics: They are used at least once a month They are used directly by the end-consumer They are non-durable They are sold in packaged form They are branded This study focuses on products like Soaps, Detergent, Antiseptic Cooking Medium and Tooth-Powder, Salt and Biscuits. All these are used on a frequent basis. Typically a consumer buys these goods at regular intervals. These are bought for personal consumption and family care. Consumers keep a little stock of these products and make frequent purchases for these. These individual items are of relatively small value, but all FMCG products put together account for a significant part of the consumers' budget. These characteristics of FMCGs have vast implications for marketers of these goods. The consumer holds a very different mindset for making these purchases. She spends little time on the purchase decision. Rarely does she look for technical specifications (in contrast to industrial goods). Brand value or recommendation of a reliable person 37 (retailer/ dealer/ friend) drives purchase decisions. Trial of a new product i.e. brand switching is often induced by heavy advertisement.

\subsection{Characteristics of the FMCG Business}

FMCG companies sell their products directly to consumers. Major features that distinguish this sector from the others are as follows:

\section{a) Low Capital Intensity:}

Most product categories in FMCG require relatively minor investment in plant and machinery and other fixed assets. Therefore shortage of product for want of capacity would be a rare phenomenon. The turnover is typically five to eight times the investment made in a Greenfield plant at full capacity. This is also due to the fact that the business being marketing driven, players do not integrate backward. Also, the business has low working capital intensity as bulk of sales from manufacturers takes place on a cash basis.

\section{b) High Initial Launch Cost:}

Nonetheless, there is a large front-ended investment made in new products including cost of product development, market research, test marketing and most importantly its launch. To create awareness and develop franchise for a new brand enormous initial expenditure is 38 required on launch advertisements, free samples and product promotions. Launch costs are as high as $50-100 \%$ of revenue in the first year and these costs progressively reduce as the brand matures, gains consumer acceptance and turnover rises. For established brands, advertisement expenditure varies from 5 - $12 \%$ depending on the categories. It is common to give occasional push by re-launches, which involves repositioning of brands with sizable marketing support.

\section{c) Technology:}

Basic technology for manufacturing is easily available. Also, technology for most products has been fairly stable. Modification/ improvement rarely changes the basic process. Nonetheless, major global players spend enormous sums on R\&D due to their ability to spread cost over the wider base of their global operations. Their R\&D efforts are towards cost effective manufacturing process without compromising on quality and functional performance. 


\section{d) Marketing Drive:}

In relative terms, marketing function has greater importance in FMCG companies. The players have to reach out to mass population and compete with several other brands, which essentially offer similar 39 products. The perceived differences are greater than the real differences in the product.

\subsection{Market Research}

Consumers' purchase decisions are based on perceptions about brands. They also keep on changing with fashion, income and changes in lifestyle. Unlike industrial products, it is difficult to differentiate products on technical or functional grounds. With increasing competition, companies spend enormous sums on product launches.

\section{a) Balance Sheets Are Misleading:}

The most critical asset for FMCG companies is represented by its brands and distribution network. Brands are bought and sold like any other assets. Typically, when an FMCG business is sold, the value of the brand is several times that of tangible assets. However as per the current accounting practices in most countries, investment made in building of brands are written off as revenue expenditure. This is due to high risk involved with a new brand, subjectivity involved in its valuation, lack of consistency and difficulty in separating a brand's value from that of tangible assets employed in the business. While a successful brand will pay back the investment several times, in case of brand failure, entire investment has to be written off. High return on net 40 worth of most established companies is also misleading due to the fact that the assets sans brands are considerably understated in the balance sheet.

\section{b) Third-party Manufacturing:}

Manufacturing of products by third party vendors is quite common. Third party manufacturing used to give fiscal advantages particularly of excise duties. These have been considerably diluted in the past 7 years of reforms. In the 1997-98 budget the government proposed to change the basis of excise levy to MRP basis. A total of 43 product categories have been brought under the MRP net in the subsequent budgets. Besides excise benefits, third party manufacturing also provides other benefits viz. flexibility in production and inventory planning as the marketing company's decision-making is liberated to a large extent from taking manufacturing overheads into account flexibility in controlling labour costs. Most small-scale third-party manufacturers have benefits of direct control of the owner and greater ability to manage local environment. The large organization also runs the risk of unionization. It is beneficial (in terms of logistics) and sometimes essential to get certain products manufactured near the 41 market. A company can tie up with several $3 \mathrm{P}$ manufacturers in separate locations, rather than set up own manufacturing facilities. The marketing company gives technology, lays down quality standards and typically exercises supervision on manufacturing, cost and quality standards. The marketing company may also co-ordinate raw material procurement to optimize on bulk discounts. While in most cases, manufacturing process is fairly simple, certain products require supply of some critical ingredients by the marketing company. It is common to find support in working capital finance also.

\section{c) Significant Presence of Unorganized Sector:}

There is a significant presence of unorganized sector in India. In the past, several factors led to mushrooming of small unorganized players with local presence viz. basic technology for most products is fairly simple and easily available. Fiscal advantages: In India, small-scale sector enjoys (the concessions however have been diluted considerably in the past few years) exemption/ lower rates of excise duty, sales tax etc. This makes them more price competitive vis-a-vis the organized sector. Remote rural markets: Due to highly scattered market and poor transport infrastructure, very few MNC companies/ organized players have been able to reach out to remote rural areas and even small towns. Low brand awareness enables local players to market their spurious look-alike brands. Cost advantage: Lower overheads are due to limited geography, family management, focused product lines and minimal expenditure on marketing.

\subsection{Global Scenario}

Major global consumer product companies (such as unlevel, Procter \& Gamble, Colgate, Nestle, Hinze etc) have a loin's share of the global market^. These companies have been established for a very lone time and possess a clutch of strong brands with proprietary technology. Most of these companies are cash rich and well managed. Their brands generate strong cash flow and allow them to reinvest in strengthening their brand equity further, with the continued promotions and advertising. They also have the financial clout to acquire small, local brands to strengthen there position in the category. These companies also make there considerable investment in R\&D to sharpen and maintain their edge in the business. Most of these global players have their origin in Europe or USA. They find their home markets saturated and are banking on the third 43 world for further growth. These comparatist are establishing their base in these countries and constantly consolidating their position by either fine -tuning their strategies to the local conditions or by formulating all the more a new approach to penetrate these markets. During last few years, particularly after reduced consumer spending during the global recession (1991-94), the new buzzword is "value for money." FMCG companies globally have embarked upon major restructuring/cost- cutting exercise as the business has become fiercely competitive. Technology, besides other factor has played a major role in checking profit-margin abrasion.

\section{Conclusion}

These characteristics of FMCGs have vast implications for marketers of these goods. The consumer holds a very different mindset for making these purchases. She spends little time on the purchase decision. Rarely does she look for technical specifications (in contrast to industrial goods). Brand value or recommendation of a reliable person 37 (retailer/dealer/friend) drives purchase decisions. Trial of a new product i.e. brand switching is often induced by heavy advertisement. 


\section{References}

[1] Jain, Ashish (2001), "The Indian FMCG Sector". ICRA Information Services, New Delhi.

[2] Catntor, Neal, (2003), "Finding Profit Opportunities in The Indian Fast Moving Consumer Goods Market" available at www.lokvani.com last visited on May 2004.

[3] "Fast Moving Consumer Goods" available at http://consumergoods.indiabizclub.com last visited on July 27, 2007,

[4] Retrieved from the website www.Indiainfoline.com on 25 August, 2006.

[5] Jha, Neeraj (2000), "Whipping up an FMCG excitement" available at http://www.Indiaexpressonline.com last visited June $19^{\prime \prime} \backslash 2008$.

[6] "The Evolution of Indian FMCG Market" available at http://www.equitymaster.com last visited February 22, 2003.

[7] Santk, Sangarneria (2000), "Chemical Business" Volumel4, Issue 2, p 29, June. 